\title{
THE CONFLICT IN UKRAINE - A NEW-GENERATION WARFARE
}

\author{
Karol SOBCZAK
}

Polish Special Forces

\begin{abstract}
The aim of this paper is to illustrate the underlying concepts and characteristics of hybrid warfare - a new type of modern warfare utilising unconventional methods and "proxy wars" which involve national minorities, terrorist groups and local communities. The paper also describes the current capabilities of states to engage in new warfare without declaring war while using all resources available, and identifies the advanced disinformation and propaganda mechanisms employed to achieve political objectives. The paper further provides a background to the outbreak of war in Ukraine by highlighting the causes and consequences of Russia's preparing for and launching the invasion of a European country in contravention of all international laws and agreements. The subject is dealt with comprehensively, from the annexation of Crimea to the destabilisation of south-eastern Ukraine by separatist military groups.

Keywords: hybrid warfare, modern warfare, propaganda, conflict in Ukraine, conflict in Donbas, ideology, chaos, manipulation, asymmetry.
\end{abstract}

Hybrid comes from the Latin word hybrida, denoting a mongrel. Hybridity relates to cross-breeding, a mixture of beings or phenomena. A hybrid is therefore an organism produced by a mixture or cross of two different, often incompatible elements. Ultimately, this brings about a variegated and non-uniform product of a cross between two seemingly incompatible elements, often difficult to predict.

In relation to contemporary armed conflicts, the term hybrid is used to describe the new warfare of the $21^{\text {st }}$ century. Incorporating the most effective forms of influence and pressure, hybridity fits ideally with new warfare. In Polish military terminology, hybrid warfare is defined as a means of achieving political or strategic objectives through planned and coordinated operations by state and non-state actors with the use of all available forms of pressure. It involves operations in all kinds of environments utilising all the defined and non-defined forms of influence to meet the objective. The definition itself came into popular use in the wake of the conflict in Ukraine, and has since gained prominence, inspiring new trends and informing new possibilities in warfare. Indeed, the conflict in Ukraine has seen a remarkable campaign that combines a variety of military and non-military approaches and operations supported by information operations. It is a new type of war - a non-declared war.

There have been many attempts over the last years to formulate a systematic definition of the term hybrid war. The subject is not new. Various forms of multifaceted warfare have been known for ages. History has witnessed great military strategists 
who have used approaches to warfare that can easily be considered prototypes of hybrid warfare. The very term hybrid warfare is fairly new, as it was not until the conflict in Ukraine that it came into use for classification purposes. Contrary to popular belief, the hybrid-warfare theory was not developed by the Russians, but by the US military. The term hybrid warfare was introduced in 2002 in Major William J. Nemeth's thesis titled Future war and Chechnya: A case of hybrid warfare. ${ }^{1}$ The thesis focused on analysing the armed conflict between the Russian Federation and Chechnya, and examined how society functioned in the context of armed operations.

The concept of engaging in armed conflicts using military and non-military methods is not new. Its beginnings can be traced back to the 1948-1960 guerrilla warfare fought by the Malayan National Liberation Army against the British Commonwealth of Nations. It was the first armed conflict to introduce the concept of "winning the hearts and minds", as proposed by General Gerald Temper in February 1952. The concept was based around kinetic and non-kinetic warfare. When talking about the conflict in question, General Temper said that "the answer [to the question of how to win the war] lies not in pouring more troops into the jungle, but in the hearts and minds of the Malayan people." In addition to military operations against communist guerrillas, the British army implemented a range of social and economic programmes to protect the Malayan population. These aimed to minimise popular support for the rebels, collect information on rebel organisations and plans, and to spread information among the local population on government services addressed to it. A similar strategy was also successfully implemented in Iraq and Afghanistan, where the ultimate objective was pursued in a multidimensional fashion, with influence being exerted on various areas of the country's life. The approach was not strictly based on combat operations. Rather, it combined many different concepts to meet the objective. The long-term warfare strategy was oriented towards achieving synergy by gaining support from the local population through large-scale economic investments and balanced military operations against terrorist groups. The concept assumed that improving living conditions, ensuring more efficient government administration, rooting out corruption and imposing the values of democracy and rule of law would lead towards the objective.

The shift in focus to the local population required an in-depth analysis of civilian, social and religious circles. The outcome of the fight for civilian support translated directly into the outcome of the war. Indeed, areas where the international coalition enjoyed popular support suffered much fewer casualties than areas where no such support was available. Individuals were the primary targets of influence, and the battle was fought for their minds. These efforts were oriented towards destroying

W.J. Nemeth, Future war and Chechnya: A case for hybrid warfare, Monterey, CA 2002 [online], http://calhoun.nps.edu/bitstream/handle/10945/5865/02Jun_Nemeth.pdf?sequence=1 [accessed on 02.09.2015]. 
the values of, and belief in, the existing system imposed by dictatorship. Drawing clear lines between who is good and who is bad, and making sure that the population thought along these lines by resorting to all available means of communication and manipulation proved to be the overarching objective. But pulling as much popular support as possible for the broad coalition, and convincing people that what the coalition was doing for the people and the country was right also proved to be the most important and most demanding task. It is obviously much more difficult to win a war without the support of the local population, with losses in men growing exponentially under such circumstances. New warfare strategies require equally innovative approaches. Focusing efforts around infantry and motorised and armoured units might help to win a battle, or even a war, but there always remains the question of "what next?".

The Russian Federation has also shown interest in the concept of hybrid warfare. In his The theory of non-linear warfare papers, Valery Gerasimov identified and defined new trends in Russian military operations. His views provide a picture of how top-ranking Russian strategists perceive new warfare. However, it should be noted that in his work entitled Ценность науки в предвидении (The value of science in prediction), Gerasimov did not use the term hybrid war. What he did, though, was illustrate the existing trends in new warfare, which is multi-level in nature and as such clearly compatible with the definition of hybrid warfare. His work investigates the challenges involved in contemporary armed conflicts and tries to answer the question of "how contemporary armies should prepare themselves for the threats of modern-day battlefields?". He pointed to asymmetric warfare as the main way to shake the existing legal system of a country. Military and non-military instruments can be used to wage total wars, and every area can be targeted.

If we look at the works of contemporary military thinkers and strategists dealing with hybrid conflicts, it becomes apparent that the idea behind these conflicts is to achieve political objectives by weakening the adversary state as an international player and ultimately to expand the range of influence of the invading country. Multi-pronged, coordinated attacks compromise various functional aspects of the state to directly weaken the state apparatus, while undermined credibility lowers morale and causes widespread fear and uncertainty. The end result is always a disorganised system. Warfare patterns may vary from conflict to conflict, as well as deviate from generally accepted standards and patterns, depending on the objective pursued by the invading country. The concept of hybrid warfare is not always clear to the public opinion, often being considered as involving a hidden agenda or having

2 В. Герасимов, Ценность науки в предвидении, „Военно-промышленный курьер”, 27 February 2013 [online], http://www.vpk-news.ru/articles/14632, English translation, https://inmoscowsshadows. wordpress.com/2014/07/06/the-gerasimov-doctrine-and-russian-non-linear-war/ [accessed on 31.08.2015]. 
a hidden meaning. Preparing for and engaging in hybrid warfare is a very complex task that requires a multidimensional synchronisation of military and non-military aspects. It involves exerting influence in every possible space, whether air, land, sea or cyber space. Hybrid warfare requires the combined effort of not only seasoned military staff, but also of information services, special forces, media PR specialists and politicians. This kind of warfare uses propaganda, political ploys, terrorism and ideology. It considers all functional aspects of the state as equally important, with every one of them being a potential target.

Hybrid conflicts work on many different levels, and it is an extremely difficult and complex task to defend against hybrid attacks. The end result of hybrid warfare is often hard to predict, since its inherent purpose is to cause chaos and internal instability, and, by extension, a social rift, through manipulation and mass media. Its seemingly unrelated effects intertwine to form a single whole as a result of meticulously orchestrated and non-linearly synchronised operations levelled against the state or its political system. Such a multi-pronged attack has the sole objective of compromising the functional foundations of the state, crushing the spirit of resistance in its society, causing a social rift and, ultimately, imposing certain systemic solutions. Exerting non-military influence on many aspects of life represents a strategy that inseparably involves much lower losses of manpower than traditional armed conflicts. It is no longer a matter of disproportions between combat capabilities. Rather, the key disproportion lies between the levels of advancement of influence and manipulation techniques employed to achieve strategic and political objectives. Even a militarily weak country can resort to highly complex technological means to launch a successful campaign against a seemingly stronger enemy. Due to the already-mentioned asymmetry, hybrid conflicts can shake the balance of military proportions, thus causing an upside-down reversal of the existing military strategies in which the disproportion of combat potentials or capabilities is of essence. It is clear, then, that hybrid warfare does not fit into the classic definition of warfare. This is a good starting point for discussion on the nature of future armed conflicts. The predictions of the nature of future armed conflicts are inconsistent and vary from strategist to strategist. Some strategists claim that traditional warfare will continue to prevail, while others predict that future warfare will combine asymmetric and even terrorist components. One thing is certain - nothing will be the same.

The new chapter that started with the outbreak of war in Ukraine has inspired far-reaching reflections on contemporary armed conflicts. The nature of the operations this war has seen fits in ideally with the definition of hybrid warfare. The characteristics of the current war in eastern Ukraine are perfectly consistent with the definition of hybrid warfare in that the war has not been officially declared and the lines of conflict are blurred, with political opposition, national minorities and even Russia-funded terrorist organisations being all actors in the conflict. Hybrid warfare in Ukraine has been a fairly popular subject, featured in many recent Polish 
works on contemporary armed conflicts. The primary reason for this is Poland's close proximity to Ukraine, and the fact that the subject continues to be relevant as war carries on in and around Donetsk, Luhansk and Mariupol. The description of the conflict as a hybrid war has caught on, and due to extensive mass-media coverage, has helped to draw the attention of the international community to Ukraine's current situation. Notably, this has been an unprecedented conflict - one of distinct asymmetry and non-linearity in which the objective of the invasion has been to expand the range of economic influence.

By utilising groups wearing unmarked uniforms, making it difficult to determine the nationality of these so-called "little green people" or "separatist groups", the invading country, in this case the Russian Federation, is trying to divert international opinion from its being the assaulting party. By shunning the term invading country or occupying country, the Russian Federation is trying to assume the role of a moderator, in order to leverage its alleged influence in international talks. This confrontation has been an obvious play of appearances in which each side of the conflict has been doing everything they can to manipulate, distort and tailor war-related information to their own means. Clearly, the Ukrainian conflict is multidimensional and complex in nature, with the Russian Federation exerting multi-pronged influence over a range of areas to attain completely different goals.

Russia's armed invasion of Ukraine aimed at the annexation of Crimea was a multifaceted, "tailor-made" effort, while the Donbas conflict in eastern Ukraine has been a mixture of disinformation operations, including disinformation of the public community. To understand exactly what has sparked this conflict, one must go back to the collapse of the Soviet Union in the late $20^{\text {th }}$ century. The collapse of the Soviet Union was caused by its deepening economic crisis, a surge in national-independence movements among subjugated national minorities and a deep rift among military elites, conflicted over army modernisation and development policies. As a result of the collapse of the post-World War II international order, the former Soviet republics regained their independence. One of the outcomes of this development was the rise of independent Ukraine, a large country with area almost twice as large as the Republic of Poland. From its inception, Ukraine had struggled with numerous social and economic problems caused by social inequalities, unemployment, corruption and ever-worsening living conditions. Torn by internal conflicts between the supporters of far-reaching reforms, necessary for economic and political recovery, and those who felt deep affiliation with Russia, Ukraine was falling into growing chaos. The appetites and expectations of Ukrainian society with regard to the improvement of Ukraine's economic situation, coupled with the need for a reorientation of the country's efforts towards becoming a rightful member of the European community, polarised and caused a deep rift in Ukrainian society.

This internal discord exposed more weaknesses of Ukraine, demonstrating significant differences in how the societies of Donbas, Crimea, Kharkiv and Odessa 
functioned. Once a monolith, in the aftermath of democratic disintegration Ukraine became very susceptible to the Russian dictatorship, inadvertently falling into its sphere of influence. This led to civil unrest in 2004 and 2005 and, consequently, to the Orange Revolution, as clashes erupted between the supporters and opponents of integration with the West. In the wake of the Orange Revolution, Ukraine turned to the West, and adopted policies designed to establish closer relations with Western European countries. Unsurprisingly, the West applauded this move, while Ukraine's eastern neighbour, the Russian Federation, expressed its strong disapproval.

As a rightful member of the European Community, Poland expressed its support for pro-Western and pro-democratic changes in Ukraine on many occasions. Polish Minister Radosław Sikorski often mentioned Ukraine in the context of the then upcoming $^{3}$ Eastern Partnership summit in Vilnius, and also discussed Ukraine's moral dilemmas in domestic and foreign policies by saying that "For Kiev, it is a choice between modernity and democracy on the one hand, and an altogether different model of civilised existence on the other. If Ukraine succeeds in meeting the requirements of the Association Agreement, Poland will advocate for Ukraine to be granted the 'European perspective' at the upcoming Eastern Partnership summit ${ }^{4}$.' Despite considerable efforts, implementing the rule of law and establishing a democratic order in the Kremlin's sphere of influence had proven to be a highly complicated challenge, especially given that the Russian special forces had been relentless in thwarting this process. Despite its pro-Western orientation, Ukraine became the arena of struggle between two conflicting world orders. For the West, it became a tool whereby to fight the hegemony of the communist regime. It was a fight for the delimitation of the sphere of influence in Eastern Europe which had been considered as being under Soviet control since $1945^{5}$. Ukraine's cultural and historic ties to Russia, as well as its geographic location and the affinity of a portion of Ukrainian society towards the former empire had caused the country to disintegrate further. Ukraine's decision to adopt European values and expand the free-trade zone had been triggering further, irreversible domestic-policy changes with long-term consequences. The growing economic disproportions and popular dissatisfaction with the rate at which the systemic changes had been progressing had led to a second wave of protests.

3 The third Eastern Partnership summit took place in Vilnius on 28-29 November 2013. It was then that Ukraine refused to sign the Association Agreement and Deep and Comprehensive Free Trade Agreement. For more on the summit, see http://www.osw.waw.pl/pl/publikacje/analizy/2013-12-04/ szczyt-w-wilnie-bez-przelomu-w-partnerstwie-wschodnim (accessed on 12/12/2014).

4 R. Sikorski, Informacja Ministra Spraw Zagranicznych o zadaniach polskiej polityki zagranicznej $w 2013$ [Statement by the Minister of Foreign Affairs on the objectives of Polish foreign policy], [in:] http://www.msz.gov.pl/pl/polityka_zagraniczna/priorytety_polityki_zagr_2012_2016/expose2/ expose_2013/ (accessed on 12.12.2014).

5 J. Kłoczowski, Europa Środkowo-Wschodnia i jej miejsce w Europie [East-Central Europe's place in Europe], "The Yearbook of the Institute of East-Central Europe", 2007, vol. 5, p. 11-32. 
Viktor Janukovych's abandonment of the European Union Association Agreement against the will of the majority of Ukraine's population triggered a second wave of protests, known as Euromaidan. This time, clashes erupted between the supporters and opponents of authoritarian rule. Although power seemed to have been equally distributed between the opposing sides, supporters of a democratic order started to grow in numbers in the face of the deep socio-political crisis. With Europe's and political opposition's support and approval for the illegal takeover of power, Maidan protests led to the ousting of legally elected president of Ukraine Viktor Yanukovych in February 2014. Shortly thereafter, following a snap election, Petro Poroshenko became the new president. As a result, the government remained in the hands of nationalist and pro-Western political powers. Russia saw their attempts at consolidating Ukraine's place within the global European system as efforts to weaken Russia and its sphere of influence. This development met with a strong response from the Russian Federation. While the newly elected authorities of Ukraine were collectively trying to rebuild the country's broken administrative-government structures, Moscow launched a military invasion. It did so under the pretence of protecting national minorities and Russian citizens against discrimination through legislation that required people to speak Ukrainian only in official dealings and prohibited the use of Russian. The strategic port of Sevastopol proved to be an important piece of the puzzle, since Ukraine's entry in NATO would mean that the port would no longer be available to Russia, thus reducing the operational range of the Black Sea Fleet. The Black Sea Fleet is a key component of the Russian navy, and the Russian dictatorship could not afford to surrender its dominance in the Black Sea region. After the collapse of the Soviet Union, the Crimean Peninsula was incorporated into Ukraine, only to be later taken away again by the Russian Federation as a result of a well-orchestrated military operation using local special self-defence forces. Russia undertook clandestine military operations using soldiers in unmarked uniforms to effectively take control of military facilities and critical infrastructure in Crimea without firing a single shot. The entire operation, justified by the Russian Federation as a response to the discrimination of Russian national minorities living in Crimea, was accomplished during spring 2014, with the tacit approval of the international community. The impromptu referendum held soon later under pressure from, and supervision of, security forces from Moscow allowed for the partition of Ukraine to be legally sanctioned. This illegal operation prompted accusations against Russia of violating a number of international agreements ${ }^{6}$.

6 The Budapest Memorandum of 05 December 1994 (under which the Russian Federation, the United Kingdom and the United States commit to respecting Ukraine's independence, sovereignty and inviolability of borders); the Treaty on Friendship, Cooperation, and Partnership between Ukraine and the Russian Federation of 31 May 1997 (under which both parties committed to respecting their territorial integrity and not to violate the existing borders between them); the Treaty on the Russian-Ukrainian Border between the Russian Federation and Ukraine of 28 January 2003 (under which Crimea was and will continue to be an integral part of Ukraine). 
Western response to this unjustified attack on a democratic European country proved to be of little significance and did not yield any concrete results. Conversely, in Russia it met with massive popular support so fervent as to come to symbolise the rebirth of Russian hegemony. Taking advantage of the firm support from Russian national minorities, Vladimir Putin realised his imperialistic vision of claiming new territories in the south of Ukraine. Moreover, the annexation of Crimea provided the Russian Federation with the additional benefit in the form of a consolidated Russian society. This major national success consolidated Putin's position as the undisputed head and political leader of the country, positioning him to once again win the 2018 presidential election, with the record support of 77 percent votes and a record election turnout. By taking control of the Sea of Azov and the Black Sea, including the air space over them, Moscow strengthened its combat capabilities, and the takeover of military facilities saved it huge amounts of lease money.

Following the successful annexation of Crimea, south-eastern Ukraine saw a surge in separatist sentiment, which led to further clashes in and around Donetsk and Luhansk. This time, the aim of the conflict was to destabilise the region in an attempt to split it from Ukraine. A certain analogy can be found here in relation to the Crimean conflict. Namely, Russian soldiers have not been officially involved in military operations in these territories. The fighting has been between Ukrainian troops and pro-Russian separatist groups. As in the case of the military operations in Crimea, pro-Russian military units are wearing unmarked uniforms in order to blur the lines of responsibility for the effects of fighting or for civilian casualties. After a period of heavy fighting in the Donetsk and Luhansk Oblasts with the ill-equipped and ill-organised sub-units from Kiev, separatist groups, supported by Russian special forces, took control of government-administration facilities. The new government in Kiev proved to be anything but prepared for a long-term armed conflict, and their counter-offensives to be ineffective and too weak to overpower the well-organised and well-prepared enemy. The passive approach of holding the defence lines and waiting for Western support undermined the Army's morale and led to massive casualties. Pro-Russian separatist groups, supported by local communities, special forces, information services, regular Russian sub-units and heavy equipment, were able to fend off the counter-terrorist operations mounted by Ukrainian national military outfits. The fact that these separatist groups were manned by alleged volunteers showed the scale and level of this conflict.

The territories claimed and occupied by separatists were proclaimed republics - called the Luhansk People's Republic and Donetsk People's Republic. Shortly thereafter, during the Novorossia Party convention on 24 May 2014, separatists put forward and signed a plan to unify the republics. Substantial political and financial support from wealthy Ukrainian oligarchs, who donated large amounts of money to help propagate the concept of independent republics, proved to be the key problem at this stage of the conflict, causing the disintegration of regional government 
administration. The resulting social discord exposed just how dependent wealthy and influential Ukrainians were on high-ranking officials and Kremlin-affiliated financial institutions.

After Petro Poroshenko was elected president, the Ukrainian public had very high hopes that the situation would go back to normal very soon. The new leader had been carrying a great responsibility for bringing the armed conflict to an end and restoring the financial sector to health as fast as possible. To achieve these goals, he had been implementing numerous economic reforms and intensifying military operations. The need for re-constructing the fragmented government administration was as important as the need for bringing an end to the conflict in eastern Ukraine. Following the intensification of counter-offensive operations, Ukraine managed to recapture a number of cities from separatists. This prompted a strong response from Moscow, which supplied separatist groups with more alleged mercenaries, as well as heavy equipment and arms (missile systems, heavy armoured vehicles and anti-aircraft systems, including the BUK-M1 surface-to-air missile system used to shoot down the Boeing 777 civilian aircraft during the $\mathrm{MH}-17$ flight).

Despite recouping their losses on an ongoing basis, both sides of the conflict proved to have shortages in manpower and equipment, meaning that the conflict had its limitations. To hold the front line, the Russian Federation had to call in further reinforcements (about 5,000 strong), effectively dealing a heavy blow to the Kiev forces. On 14 August, under the pretence of providing humanitarian aid to civilians, Russia used the open Russian-Ukrainian border to transport, in white-painted trucks, heavy arms and equipment into Ukraine ${ }^{7}$ to enable separatist groups to continue fighting along the entire front. According to US Army estimates, in March 2015 there were about 12,000 Russian soldiers fighting alongside separatist groups in eastern Ukraine. These largely included military advisers and operators of heavy and advanced equipment in the Donetsk and Luhansk Oblasts ${ }^{8}$.

Four years on, still unresolved, the conflict is pushing Ukraine's economy to the brink of collapse, while giving Russia leverage in its bilateral relations with the European Union. The reasons for this can be attributed, above all, to the awful state of the Ukrainian Army, as well as to the ongoing provision of funds and equipment to separatist militias by the Russian Federation. The country's financial struggles, lack of proper equipment and arms, and gross tactical incompetence of Ukrainian soldiers have directly led to stagnation in the area of the armed conflict. Another issue relates to the far-reaching propaganda campaign run by Russian secret services

7 A. Rácz, Putin's Humanitarian Convoy and the Road to Ukraine: Russia may intend to change the course of the fighting, The Finnish Institute of International Affairs, FIIA Comment 10/2014, Helsinki 2014.

8 S. Siebold, Some 12,000 Russian soldiers in Ukraine supporting rebels: U.S. commander, Reuters [online] <http://www.reuters.com/> (04.11.2015). 
to win over increasing numbers of uniformed troops and local citizens. Seduced and manipulated by illusory and empty promises, native citizens of Ukraine switch to the enemy's side in a search for a better future for themselves and their families. In doing so, they are trying to put an end to the bloodshed and secure a safe future. Financial promises, around which people can build a safe future, are of equal importance here. Regrettably, the fighting continues, and neither side of the conflict has been willing to respect the terms of the several ceasefires that have already been agreed. Politicians and soldiers start with declaring their commitment to respecting bilateral agreements, only to later re-engage in fighting under the pretence of retaliation for alleged enemy provocations amidst mutual accusations of breaking ceasefire. The heaviest fighting has been taking place in an around Debaltseve, which is a strategic region. Separatists claim that the agreements do not apply to Debaltseve, so it is excluded from ceasefire. Operating on this premise, they are consistently taking control over the region with Russian support. Ukraine's situation is becoming increasingly serious, and its defeat in individual regions seems inevitable. Despite the heavy losses, it is trying to prepare and deploy further sub-units to relieve or reinforce the front line. Currently, there is no end in sight to this conflict, however, and Western support seems to be the only viable option. Pressed up against the wall, the authorities in Kiev are determined to draw financial and military support from the international community by exerting political and economic pressure on the invading country.

On the other side of the conflict, Russia's strategy of sponsored warfare seems to bring the expected benefits. By waging a proxy war on Ukraine and inciting hatred against it, while promoting deep-seated national values, the Russian Federation is well-positioned to prevent Ukraine's integration with the European Union and NATO for years to come. This strategy has proven extremely effective given the entirely passive attitude of Western countries, which have done essentially nothing to help the invaded country apart from repeated public condemnations and protests against Russia's violation of all international laws and agreements. By contrast, Kremlin has been supporting this regional conflict outside its territory with little financial effort, thus exposing the weakness and internal divide of the West. As long as the Donbas conflict is considered a local affair, no third countries will become involved, since they are not willing to put the safety of their citizens at risk, and would rather sacrifice Ukraine for the general good. Putin's tactic of creating a situation of constant tension and threat, combined with the vast capabilities in terms of manpower, equipment and territory, as well as steadily increased defence funding and financing of army restructurisation, and with the nuclear arsenal held by Russia, has proven to be an effective deterrent that has yielded the expected results. It seems that the only way to make an impact on the Russian dictatorship without resorting to full-on armed conflict is to mobilise absolute solidarity between European countries and maintain close relations with the world's largest military power - the United States. 
Achieving a military balance by increasing defence spending in EU countries and developing new strategies and common military structures are some of the challenges that the European community will have to face. Potentially, one of the key ways to do this is by keeping in place and expanding political and financial sanctions, as well as impeding the progress of Russia's major economic projects, such as Nord Stream $2^{9}$, in order to put a strain on its finances, thus prompting a quicker end to the Ukraine conflict.

\section{BIBLIOGRAPHY}

[1] Герасимов В., Ценность науки в предвидении, „Военно-промышленный курьер”, 27/02/2013 [online], http://www.vpk-news.ru/articles/14632, English translation, https://inmoscowsshadows. wordpress.com/2014/07/06/the-gerasimov-doctrine-and-russian-non-linear-war/ (accessed on 31.08.2015).

[2] KŁoczowski J., Europa Środkowo-Wschodnia i jej miejsce w Europie [East-Central Europe’s place in Europe], "The Yearbook of the Institute of East-Central Europe", 2007, vol. 5, pp. 11-32.

[3] Nemeth W.J., Future war and Chechnya: A case for hybrid warfare, Monterey, CA 2002 [online], http://calhoun.nps.edu/bitstream/handle/10945/5865/02Jun_Nemeth.pdf?sequence=1 (accessed on 02.09.2015).

[4] RÁcz A., Putin's Humanitarian Convoy and the Road to Ukraine: Russia may intend to change the course of the fighting, The Finnish Institute of International Affairs, FIIA Comment 10/2014, Helsinki 2014.

[5] Siebold S., Some 12,000 Russian soldiers in Ukraine supporting rebels: U.S. commander, Reuters [online] <http://www.reuters.com/> (04/11/2015).

[6] Sikorski R., Statement by the Minister of Foreign Affairs on the objectives of Polish foreign policy, [in:] http://www.msz.gov.pl/pl/polityka_zagraniczna/priorytety_polityki_zagr_2012_2016/ expose2/expose_2013/(accessed on 12/12/2014).

[7] The Budapest Memorandum of 05 December 1994 (under which the Russian Federation, the UK and the US commit to respecting Ukraine's independence, sovereignty and inviolability of borders); the Treaty on Friendship, Cooperation, and Partnership between Ukraine and the Russian Federation of 31 May 1997 (under which both parties committed to respecting their territorial integrity and not to violate the existing borders between them); the Treaty on the Russian-Ukrainian Border between the Russian Federation and Ukraine of 28 January 2003 (under which Crimea was and will continue to be an integral part of Ukraine).

[8] The third Eastern Partnership summit took place in Vilnius on 28-29 November 2013. It was then that Ukraine refused to sign the Association Agreement and Deep and Comprehensive Free Trade Agreement. For more on the summit, see http://www.osw.waw.pl/pl/publikacje/ analizy/2013-12-04/szczyt-w-wilnie-bez-przelomu-w-partnerstwie-wschodnim (accessed on $12 / 12 / 2014)$.

9 Nord Stream 2 is an infrastructure project involving the construction of a natural-gas pipeline in the Baltic Sea. The pipeline will be used to transmit natural gas from the world's largest gas resource in Russia to the internal gas market of the European Union, enabling the EU to meet its gas demand while curbing its own gas production. 


\section{KONFLIKT NA UKRAINIE - WOJNA NOWEJ GENERACJI}

Abstrakt. Celem artykułu jest przedstawienie idei oraz charakterystyki nowego rodzaju konfliktu zbrojnego, jakim jest wojna hybrydowa - wojna niekonwencjonalna, nowoczesna, toczona przy wykorzystaniu mniejszości narodowych, ugrupowań terrorystycznych czy lokalnej społeczności, tzw. „wojna zastępcza”. Przybliżono zdolności prowadzenia nowoczesnych działań wojennych bez ich oficjalnego wypowiedzenia przy wykorzystaniu wszelkich dostępnych środków oraz zwrócono uwagę na wykorzystywanie zaawansowanych mechanizmów dezinformacji i propagandy do osiągania zakładanych celów politycznych. Następnie przedstawiono genezę zarzewia konfliktu i wybuchu wojny na Ukrainie poprzez uwypuklenie przyczyn i następstw przygotowania i przeprowadzenia łamiącej wszelkie prawa i umowy międzynarodowe inwazji na europejski kraj, poczynając od zaanektowania Półwyspu Krymskiego poprzez destabilizację południowo-wschodniej części Ukrainy przy wykorzystaniu separatystycznych ugrupowań bojowych.

Słowa kluczowe: wojna hybrydowa, wojna nowoczesna, propaganda, konflikt na Ukrainie, konflikt w Donbasie, ideologia, chaos, manipulacja, asymetryczność. 